\title{
ESTIMATING TRADE ELASTICITIES FOR SOUTH AFRICA'S AGRICULTURAL COMMODITIES FOR USE IN POLICY MODELLING
}

\author{
By: S.M. Ntombela', M. Kalaba ${ }^{2}$, and H. Bohlmann ${ }^{3}$
}

\begin{abstract}
The computable general equilibrium (CGE) model is often used to analyse the effects of policy changes because of its ability to capture multisectoral interlinkages within the economy. The results of a CGE analysis largely depend on the database, policy shock and elasticities. Trade elasticities, such as the Armington, play a central role in CGE models to determine the demand substitution between commodities from different sources as a result of changes in relative prices. Because of their role, modellers are keen to know the correct elasticities for use in CGE models. Despite their importance, elasticities are often outdated for South African agricultural commodities, leaving researchers to rely on value judgement. We address this limitation by estimating the Armington and export supply elasticities for individual and aggregate agricultural commodities using updated time-series data (19802016). The results for the two sets of trade elasticities show that estimates for an aggregate agriculture tend to be inelastic compared to estimates for an individual product, indicating a higher sensitivity of products to relative price changes. The Armington estimates were found to be closer to unity for the majority of products, suggesting that agricultural imports are imperfect substitutes for domestic products. The export supply elasticities for grains were found to be more elastic than for fruit and meat, implying that domestic grain production is relatively more responsive to price changes in the export markets. The long-run estimates for the two sets of elasticities were found to be larger than the short-run estimates for all agricultural products.
\end{abstract}

Keywords: agricultural trade, Armington, computable general equilibrium, elasticities

JEL classification: Q17, C12, C68, F17

\footnotetext{
${ }^{1} \mathrm{PhD}$ candidate in the agricultural economics department at the University of Pretoria, corresponding author sifiso@igrodeals.co.za

${ }^{2}$ Agricultural economics department, University of Pretoria

${ }^{3}$ Economics department, University of Pretoria
} 


\section{Introduction}

Understanding the implications of policy changes for key economic variables such as the traded quantity, employment and welfare growth has always been a prime focus of policy makers in South Africa and internationally. To gain this understanding, researchers have used economic models, such as the partial and general equilibrium, to convert the impacts of policy changes into price effects (McDonald and Kirsten, 1999; and Reynolds, 2009). However, general equilibrium models like a CGE model are often preferred in the policy analysis exercise because of their ability to capture the multiple input and output linkages, thus measuring the policy effects on all sectors of the economy. In the CGE models, the extent in which policy changes affect individual economic variables depends on the size of a policy shock, the constructed database and the elasticities used in the model. Hillberry and Hummels (2013: 1213) argue that, while CGE models depend on various inputs, trade elasticities are of particular importance because they significantly affect the modelled effects of policy changes on trade patterns and the welfare of the countries.

When talking about trade elasticities, we refer to two sets of elasticities. First is the input demand elasticity, also known as the Armington elasticity, which is commonly used in a CGE model to distinguish between the substitutability between consumption of domestic goods versus imported goods. Second is an export supply elasticity, which distinguishes between the substitutability between production of domestic goods for the local market versus production for the export market. These elasticities allow a CGE model to measure the percentage of variation in one variable (e.g. quantity demanded) in comparison to a variation in another variable (e.g. price). According to Hillberry and Hummels (2013) and Annabi et al. (2006), the choice of elasticities for use in CGE models is very critical, as they affect the functionality and predictive power of CGE models.

Despite the importance of trade elasticities, the Armington elasticities are rarely available, or are outdated in the literature, more so for the agricultural products of South Africa. The latest available Armington estimates for South African agricultural commodities were estimated by Ogundeji et al. (2010), using seasonal data from 1995 to 2006. The Armington estimates by Ogundeji et al. (2010) are not only considered outdated, but they were estimated for meat and grain products, giving rise to a need to update and expand the estimates to other agricultural products such as fruits, vegetables and processed food. With regards to the export supply 
elasticity, there are no known estimates in the literature, implying that researchers depend on value judgment when assigning export supply elasticities in models.

The non-availability of updated Armington elasticities and the lack of econometrically estimated export supply elasticities for agricultural products can be attributed to data challenges that limit the estimation. Hillberry and Hummels (2013) found that the data issue also limits the estimation of trade elasticities for many countries in the world. In this paper, we seek to address the lack of updated Armington elasticities, and the non-existence of export supply elasticities for agricultural products of South Africa that can be used in CGE models. The key contribution of this paper is to provide updated and expanded Armington elasticities for agricultural products that cover grains, fruits, vegetables, meat and processed food products. Furthermore, the paper provides export supply estimates for agricultural products, which are regarded as first estimates that have been estimated econometrically in the country.

\section{Review of selected studies on trade elasticity estimation}

In the theory of demand, it has been proven by Armington (1969) that goods of the same kind, but differing in origin, are imperfect substitutes. Following his findings, most neoclassical models such as the CGE model assume that there are continuous substitution possibilities between imported and domestic goods. These substitutions between goods in the models are managed by elasticities. However, the appropriate elasticities to be used in CGE models remain a cause of debate among CGE modellers all over the world, hence there are many studies with varying elasticities in the literature. Moreover, Annabi et al. (2006: 26) note that most trade elasticity studies focus on estimating the Armington elasticity, and then apply judgemental approaches based on the literature to assign export supply elasticities. Similar observations were made by Hillberry and Hummels (2013: 1426) and McDonald and Punt (2005: 85), who stated that the CGE literature is dominated by the Armington elasticity, while export supply elasticities are less visible.

The Armington elasticity is specified using a constant elasticity of substitution (CES) specification, where the first-order condition that drives the optimal quantities of domestic and imported goods is mainly dependent on the relative prices of domestic versus imported goods (Annabi et al., 2006). Among the popular studies that have estimated the Armington elasticity using the CES specification is that of Reinert and Roland-Holst (1992). They estimated the Armington elasticities for mining and manufacturing goods in the United States of America (USA) using the ordinary least squares (OLS) model. They found elasticities 
ranging from 0.14 to 3.49 , suggesting that the mining and manufacturing products of the USA are far from perfect substitutions in the international market. Kapuscinski and Warr (1999) estimated the Armington elasticities for the Philippine economy, covering agriculture, mining, food and manufacturing products and applying the OLS and the error correction model (ECM). They found that the majority of Philippine products had elasticities that are greater than 1; however, the overall Armington elasticities ranged between 0.2 and 4 (Kapuscinski and Warr, 1999: 268).

In South Africa, Gibson (2003), Naude et al. (1999), and Ogundeji et al. (2010) have estimated the Armington elasticities using the OLS and ECM methods. The first two studies focused on industrial, manufacturing and mining commodities, whereas the latter estimated elasticities for selected agricultural goods. Ogundeji et al. (2010) found that soybeans and beef are the most sensitive products, with elasticities of 3.47 and 1.21 respectively. Looking at both the local and international literature, it is evident that Armington elasticities vary across commodities and countries, suggesting the need to estimate them for all major South African agricultural products.

As mentioned earlier, both the domestic and international literature is dominated by Armington elasticities, with limited studies on export supply elasticities. The export supply elasticity is specified using a constant elasticity of transformation (CET) specification, where the first-order condition that drives the optimal quantities of domestic and exported goods is mainly dependent on the relative prices of domestic versus exported goods (Annabi et al., 2006). Pertaining to the estimation method for the CET export supply elasticity, De Melo and Robinson (1985: 14) argue that an analogous assumption to the Armington can be applied in export supply elasticities, where goods sold on the domestic market are assumed to be different from those sold on the world market. Based on this notion, Annabi et al. (2006) and Hillberry and Hummels (2013) reviewed different studies across the world that have estimated export supply elasticity. Annabi et al. (2006: 28) reported CET export supply elasticities that ranged between 0.03 for machinery to 2.79 for oils and fats. They found that the export supply elasticities for the majority of agricultural products ranged between 0.56 and 2.79. Hillberry and Hummels (2013: 1250) reported export supply elasticities ranging from 1.5 to 2.2 for Canadian products, whereas they range between 0.33 and 0.38 for USA products. 


\section{An overview of the commodities used in estimation}

From a South African agricultural perspective, Ogundeji et al. (2010) provided a good insight into the trade elasticities for individual agricultural products, but their focus was on meat and grain products, thus creating a need to expand the Armington estimates to other agricultural products. In this paper we improve on Ogundeji et al. (2010) by expanding the product range to cover the grain (maize, wheat and sorghum); fruit (apples, grapes, oranges and avocados); vegetable (potatoes and tomatoes); meat (beef, poultry and swine); and processed food (milk, wine and sugar) products. In addition to Armington, we estimated the CET export supply elasticity for all the aforementioned products, as presented in Table 1.

Table 1: Individual product shares of total agricultural production and trade

\begin{tabular}{|c|c|c|c|c|c|}
\hline $\begin{array}{l}\text { Agricultural } \\
\text { sub-sector }\end{array}$ & $\begin{array}{c}\text { Agricultural } \\
\text { products }\end{array}$ & HS codes & $\begin{array}{c}2016 \text { gross } \\
\text { production value: } \\
1000 \mathrm{ZAR}\end{array}$ & $\begin{array}{c}2012-2016 \\
\text { average export } \\
\text { share: } \%\end{array}$ & $\begin{array}{c}2012-2016 \\
\text { average import } \\
\text { share: } \%\end{array}$ \\
\hline \multirow{3}{*}{ Grains } & Wheat & 1001 & 7107286 & 1.75 & 6.92 \\
\hline & Maize & 1005 & 29824219 & 2.27 & 3.35 \\
\hline & Sorghum & 1007 & 459167 & 0.01 & 0.24 \\
\hline \multirow{4}{*}{ Fruits } & Avocados & 080440 & 1036570 & 0.39 & 0.06 \\
\hline & Oranges & 080510 & 10176160 & 6.98 & 0.03 \\
\hline & Grapes & 080610 & 5078477 & 4.94 & 0.16 \\
\hline & Apples & 080810 & 5501300 & 1.69 & 0.01 \\
\hline \multirow{2}{*}{ Vegetables } & Potatoes & 0701 & 6132450 & 0.35 & 0.00 \\
\hline & Tomatoes & 0702 & 1735036 & 0.08 & 0.01 \\
\hline \multirow{3}{*}{ Meat } & Beef & 0201-02 & 10272080 & 0.51 & 0.66 \\
\hline & Swine & 0203 & 5793659 & 0.17 & 1.06 \\
\hline & Poultry & 0207 & 40472219 & 0.63 & 6.18 \\
\hline \multirow{3}{*}{ Processed } & Sugar & 1701 & 8507959 & 6.86 & 4.06 \\
\hline & Wine & 2204 & 36101365 & 6.23 & 0.44 \\
\hline & Milk & 0401 & 16463166 & 0.19 & 0.15 \\
\hline Other & \multicolumn{2}{|c|}{ Other agricultural products } & 81961984 & 67 & 77 \\
\hline Aggregated & \multicolumn{2}{|l|}{ Agriculture } & 266623097 & 100 & 100 \\
\hline
\end{tabular}

Source: Department of Agriculture, Forestry and Fisheries (DAFF 2018)

Table 1 presents the selected products, which account for 70 per cent, 89 per cent and 58 per cent shares in the gross production value for field crops, horticulture and livestock respectively. These products also account for large shares of agricultural exports and imports, measured in average share to total export and imports between 2012 and 2016 (Table 1). The 
criterion of selecting products based on shares to total agricultural trade and production ensures that the products that will potentially have the greatest impact on CGE model results, are selected. The next section provides a discussion of the methods applied to estimate trade elasticities.

\section{Methods for estimating trade elasticities}

\subsection{Armington elasticity}

To estimate the updated Armington elasticities for agricultural products, we follow the method applied by Kapuscinski and Warr (1999), Ogundeji et al. (2010), and Reinert and Roland-Holst (1992). This method assumes a consumer with a well-behaved utility function. The hypothetical consumer obtains utility from a composite $(Q)$ of imported $\left(Q_{M}\right)$ and domestic $\left(Q_{D}\right)$ goods, and it is assumed that there are continuous substitution possibilities. The consumer's decision problem is then to choose a mixture of $Q_{M}$ and $Q_{D}$ that minimises expenditure, given the respective import price $\left(P_{M}\right)$ and domestic price $\left(P_{D}\right)$ and the desired level of $Q$. The Armington specification of the composite goods demand is specified as:

$$
Q=\mathrm{A}\left[\beta Q_{M}^{-\varphi}+(1-\beta) Q_{D}^{-\varphi}\right]^{-\frac{1}{\varphi}}
$$

where $\mathrm{Q}$ is sub-utility over the domestic and import goods, $\mathrm{A}$ is an efficiency parameter, $\beta \mathrm{s}$ are share parameters in the demand function, $\varphi$ is the substitution parameter. The relationship between the substitution parameter and $\sigma$, which is the elasticity of substitution between imported and domestic commodities, is given by $\sigma=\frac{1}{1+\varphi}$. Following the standard assumptions of a well-behaved utility function, continuous substitution between two goods, as well as weak separability of product categories, the solution to the consumer's optimisation problem is to choose imports and domestic goods whose ratios satisfy the first-order condition given by:

$$
\frac{Q_{M}}{Q_{D}}=\left[\frac{P_{D}}{P_{M}} \frac{\beta}{1-\beta}\right]^{\sigma}
$$

Under the assumption that utilities in composite consumption are weakly separable, Armington elasticities can be estimated for disaggregated commodity categories by taking the logarithmic form of the above first-order condition, which yields the following: 


$$
\ln \left(\frac{Q_{M}}{Q_{D}}\right)=\sigma_{0} \ln \left(\frac{\beta}{1-\beta}\right)+\sigma_{1} \ln \left(\frac{P_{D}}{P_{M}}\right)+\varepsilon
$$

where $Q_{M}$ is the quantity of imported goods, $Q_{D}$ is the quantity of domestic goods, and $\varepsilon$ is the error term, which is assumed to be independently and identically distributed with zero mean and constant variance. Equation 3 can be simplified as:

$$
\mathrm{Y}_{i}=\phi_{0}+\phi_{1} X_{i}+\varepsilon
$$

where $Y_{i}=\ln \left(\frac{Q_{M}}{Q_{D}}\right)$ is a dependent variable, $\phi_{0}=\sigma_{0} \ln \left(\frac{\beta}{1-\beta}\right)$ is an arbitrary constant, $\phi_{1=} \sigma_{1}$ is the elasticity of substitution between imports and domestic goods, and $X_{i}=\ln \left(\frac{P_{D}}{P_{M}}\right)$ is an explanatory variable. According to Kapuscinsky and Warr (1999: 262), the estimation of Equation 4 may potentially lead to problems because it does not adequately capture the dynamic relationships between imports, domestic production and prices. Furthermore, it does not capture factors such as the regulations and tariffs that affect imports entering the country. We control for the regulations and trade distortionary measures by including a dummy variable. The dummy variable captures the trade and market policy reforms adopted in the South African agricultural sector pre- and post-1994. Specifically, joining the World Trade Organisation (WTO) in 1995 and promulgating the Marketing of Agricultural Products Act 47 of 1996 led to the abolishment of marketing control boards, thus the removal of import quotas and tariff reductions, as well as other market regulations in the sector.

The dummy variable is activated in the year 1998, as the majority of deregulation measures took effect around 1997. In the estimation, the dummy variable has a value of zero between 1980 and 1997, and a value of one from 1998 to 2016. Annabi et al. (2006: 18) also argue that adding a variable that reflects the overall level of an economic activity, such as real GDP, can help to account for the pressures on demand. This variable also assists in controlling for the relationship between local economic activities and the demand for imported products. To distinguish between short-run and long-run Armington elasticities, Ogundeji et al. (2010: 128) show that Equation 4 can be further adjusted to distinguish between short-run and long-run elasticities by including a one-period lag of the dependent variable on the right-hand side of the equation. The modified Armington elasticity specification used in this paper, which takes into account trade distortionary measures and demand pressures on the economy, and distinguishes between short-run and long-run estimates, is given by: 


$$
\mathrm{Y}_{i}=\phi_{0}+\phi_{1} X_{i}+\phi_{2} \mathrm{Y}_{i_{t-1}}+\phi_{3} \mathrm{G}+\phi_{4} \mathrm{Z}+\varepsilon
$$

where $G=\ln G D P$ is the variable capturing demand pressures and the relationship between local economic activities and import demand; $\mathrm{Z}$ is a dummy variable controlling for trade regime changes in the South African agricultural economy; and $\mathrm{Y}_{i_{t-1}}$ is a one-period lag in the dependent variable. The short-run elasticity is given by $\sigma_{\text {short }}=\phi_{1}$, and long-run elasticities can be calculated using $\sigma_{\text {long }}=\frac{\phi_{1}}{\left(1-\phi_{2}\right)}$, if $0<\phi_{2}<1$; otherwise only short-run estimates are reported.

\subsection{Export supply elasticity}

According to De Melo and Robinson (1985: 15), exports and goods sold on the domestic market within the same sector classification are assumed to be imperfect substitutes. They argue that the domestic producer makes a composite commodity, $Q$, which is an aggregation of goods suitable for the domestic market, $Q_{D}$, and goods suitable for the export market, $Q_{E}$. The producer has a transformation function that determines the trade-off between producing goods with the same sectoral classification for the domestic and export markets. In the CGE context, the producer's decision is modelled using the export supply elasticity, which is specified using a constant elasticity of transformation. This elasticity measures the responsiveness of export supply to changes in the relative prices of domestic and export markets. The CET export supply elasticity is specified as follows:

$$
Q=\mathrm{A}\left[\delta Q_{E}^{\rho}+(1+\delta) Q_{D}^{\rho}\right]^{\frac{1}{\rho}}
$$

where $\mathrm{A}$ is an efficiency parameter, $\delta^{\prime} s$ are share parameters and $\rho$ is the transformation parameter. The relationship between the transformation parameter and the transformation elasticity, $\Omega$, is given by $\Omega=\frac{1}{\rho-1}$. Given this formulation, one can derive expressions for the derived demand for exports and domestic under the assumption that producers maximize profits, and hence, equate the marginal rate of transformation between exports and domestic to their price ratio (De Melo and Roninson, 1985: 15). Applying the algebra that is similar to that used in case of the Armington elasticities, the optimal allocation depending on the ratio of export to domestic prices is given by the following first-order condition:

$$
\frac{Q_{E}}{Q_{D}}=\left[\frac{P_{E}}{P_{D}} \frac{1-\delta}{\delta}\right]^{\Omega}
$$


The CET export supply elasticities can be estimated for disaggregated commodity categories by taking the logarithmic form of the above first-order condition, which yields the following:

$$
\ln \left(\frac{Q_{E}}{Q_{D}}\right)=\Omega_{0} \ln \left(\frac{1-\delta}{\delta}\right)+\Omega_{1} \ln \left(\frac{P_{E}}{P_{D}}\right)+\varepsilon
$$

where $Q_{E}$ and $P_{E}$ are export quantity and export price, $\Omega_{1}$ is the elasticity of transformation and $\varepsilon$ is the error term, which is assumed to be independently and identically distributed with zero mean and constant variance. Equation 8 can be simplified as:

$$
\mathrm{Y}_{E}=\psi_{0}+\psi_{1} X_{E}+\varepsilon
$$

Where $\mathrm{Y}_{E}=\ln \left(\frac{Q_{E}}{Q_{D}}\right)$ is the dependent variable, $\psi_{0}=\Omega_{0} \ln \left(\frac{1-\delta}{\delta}\right)$ is an arbitrary constant, $\psi_{1}=\Omega_{1}$ is the transformation elasticity, and $X_{E}=\ln \left(\frac{P_{E}}{P_{D}}\right)$ is an explanatory variable. To control for trade distortionary measures, we included a dummy variable that is similar to that used in the specification of the Armington elasticity. We also included the one-period lag of the dependent variable to distinguish between the short-run and long-run CET export supply elasticities. The export supply elasticity was then estimated using the following equation:

$$
\mathrm{Y}_{E}=\psi_{0}+\psi_{1} X_{E}+\psi_{2} \mathrm{Y}_{E_{t-1}}+\psi_{3} Z+\varepsilon
$$

where $\mathrm{Y}_{E_{t-1}}$ is a one-period lag in the dependent variable, and $\mathrm{Z}$ is a dummy variable controlling for trade-distorting factors in South African agriculture. The short-run elasticity is given by $\Omega_{\text {short }}=\psi_{1}$, and long-run elasticities can be calculated using $\Omega_{\text {long }}=\frac{\psi_{1}}{\left(1-\psi_{2}\right)}$, if $0<\psi_{2}<1$; otherwise only short-run estimates are reported.

\subsection{Data characteristics and sources}

Two sets of trade elasticities are estimated in this paper using annual data series that range from 1980 to 2016. The longer time period is chosen to increase the degrees of freedom and capture the long-run changes in economic variables, thus obtaining robust econometric results. The Armington elasticity for individual and aggregate agricultural products is estimated using data series such as real import quantities, import prices, domestic quantities, domestic prices, real gross domestic product (GDP), and a dummy variable. In the case of export supply elasticities, export quantities and export prices are required for the estimation. As explained earlier, the dummy variable controls for the market and trade policy reforms 
adopted in South African agriculture post-1994. The actual abolishment of control boards and other regulatory measures was implemented around 1997, hence the dummy variable is activated from 1998 in the simulations, which means that it has a value of zero from 1980 to 1997 and a value of one from 1998 to 2016.

Various sources of data are used, including the Agricultural Abstracts, which provide official statistics for the agricultural sector and are published by the Department of Agriculture, Forestry and Fisheries (DAFF, 2018) on an annual basis. Time-series data from Liebenberg et al. (2015) is also used, and this provides the long-term series data on variables such as agricultural values and prices. Other data sources include the World Bank commodity database, and the database of the Food and Agriculture Organization (FAO) of the United Nations. These two global databases provide country-level commodity prices, including import and export prices as well as world trade flows. The usage of global databases allows a comparison with data sourced locally, which subsequently gives credibility to the data series used in this paper.

In terms of evaluating and understanding data characteristics for each data series used, the Augmented Dickey Fuller (ADF) diagnostic test was performed on each logged-transformed data series. The ADF tests the null hypothesis of the presence of a unit root in a data series. Regressing a data series that has a unit root could cause the problem of a spurious regression, hence there is a need to test all data series for the presence of a unit root. The test results for the ADF unit root are presented in Table 2 in Appendix A. Looking at the results, it can be observed that the null hypothesis of a unit root cannot be rejected at the 5 per cent significance level for real GDP, domestic quantities and export quantities for all individual products at logged levels, suggesting the presence of a unit root. In addition, the null hypothesis for domestic price, import quantities, import price and export prices series cannot be rejected for the majority of products, implying that the majority of these variables also have a unit root.

The data series that do not have a unit root at logged levels include domestic prices for maize, avocados and sugar; import quantities for wheat and poultry; import prices for wheat, swine and sugar; and export prices for wheat and poultry products. When the data series are differenced, the ADF results indicate that the null hypothesis of a unit root can be rejected at the 1 per cent and 5 per cent levels of significance for all data series at the first difference level. This clearly suggests a need to difference some data series that have a unit root at the 
logged level. Controlling for a unit root through the method of differencing the data series ensures that spurious regressions are avoided when estimating the Armington and export supply elasticities.

\section{Results and Discussions}

\subsection{Armington elasticity results}

Using Equation 5 described above, the short- and long-run results of the Armington elasticities for the South African individual and aggregate agricultural commodities are presented in Table 3. Firstly, all the estimated elasticities show the expected positive sign, which implies that Equation 5 yielded the correct results. Secondly, all the estimated elasticities are statistically significant, either at the 99 per cent, 95 per cent or 90 per cent confidence level, suggesting a good model fit; in other words, the model results are explained by the selected explanatory variables. In addition, the long-run elasticities for all products are on average larger than the short-run elasticities and significantly different from the unity, which implies that agricultural imports are imperfect substitutes for domestic goods.

Table 3: CES Armington elasticities for individual and aggregate agriculture products

\begin{tabular}{|c|c|c|c|c|c|c|c|}
\hline \multirow{2}{*}{ Sub-sector } & \multirow{2}{*}{ Commodities } & \multirow{2}{*}{ HS code } & \multicolumn{2}{|c|}{ Armington elasticity } & \multirow{2}{*}{ Dummy } & \multirow{2}{*}{ GDP } & \multirow{2}{*}{ R-square } \\
\hline & & & Short-run & Long-run & & & \\
\hline \multirow{3}{*}{ Grains } & Maize & 1005 & $\begin{array}{c}0.868 * * * \\
(0.221)\end{array}$ & $\begin{array}{c}2.399 * * * \\
(0.119)\end{array}$ & $\begin{array}{c}0.101 \\
(0.087)\end{array}$ & $\begin{array}{c}1.650 \\
(2.403)\end{array}$ & 0.36 \\
\hline & Wheat & 1001 & $\begin{array}{c}0.98 * * * \\
(0.268)\end{array}$ & $\begin{array}{c}1.648 * * * \\
(0.151)\end{array}$ & $\begin{array}{c}0.189 * * * \\
(0.055)\end{array}$ & $\begin{array}{c}1.936 \\
(1.548)\end{array}$ & 0.69 \\
\hline & Sorghum & 1007 & $\begin{array}{c}1.818 * * * \\
(0.425)\end{array}$ & $\begin{array}{c}2.171 * * * \\
(0.138)\end{array}$ & $\begin{array}{l}-0.250 \\
(0.203)\end{array}$ & $\begin{array}{l}-0.316 \\
(4.223)\end{array}$ & 0.71 \\
\hline \multirow{4}{*}{ Fruits } & Apples & 080810 & $\begin{array}{c}0.506^{* * *} * \\
(0.157)\end{array}$ & & $\begin{array}{l}-0.017 \\
(0.090)\end{array}$ & $\begin{array}{l}-3.013 \\
(2.506)\end{array}$ & 0.51 \\
\hline & Grapes & 080610 & $\begin{array}{c}0.717 * * * \\
(0.203)\end{array}$ & & $\begin{array}{l}-0.009 * \\
(0.040)\end{array}$ & $\begin{array}{c}-0.156 \\
(1.114)\end{array}$ & 0.53 \\
\hline & Oranges & 080510 & $\begin{array}{l}0.245^{*} \\
(0.143)\end{array}$ & $\begin{array}{c}0.252 \\
(0.113)\end{array}$ & $\begin{array}{c}0.031 \\
(0.036)\end{array}$ & $\begin{array}{l}-0.367 \\
(0.729)\end{array}$ & 0.57 \\
\hline & Avocados & 080440 & $\begin{array}{c}0.270 * * * \\
(0.107)\end{array}$ & $\begin{array}{l}0.509^{*} \\
(0.138)\end{array}$ & $\begin{array}{l}-0.006 \\
(0.042)\end{array}$ & $\begin{array}{l}-0.090 \\
(1.162)\end{array}$ & 0.41 \\
\hline \multirow{2}{*}{ Vegetables } & Potatoes & 0701 & $\begin{array}{l}0.430 * \\
(0.271)\end{array}$ & $\begin{array}{c}0.522 \\
(0.181)\end{array}$ & $\begin{array}{c}-0.234 * * * \\
(0.08)\end{array}$ & $\begin{array}{l}-0.318 \\
(2.237)\end{array}$ & 0.53 \\
\hline & Tomatoes & 0702 & $\begin{array}{c}0.761 * * \\
(0.319)\end{array}$ & $\begin{array}{c}0.810 * * \\
(0.329)\end{array}$ & $\begin{array}{c}-0.021 \\
(0.1229)\end{array}$ & $\begin{array}{l}-2.048 \\
(3.456)\end{array}$ & 0.42 \\
\hline \multirow{3}{*}{ Meat } & Beef & 0201-2 & $\begin{array}{l}0.911^{*} \\
(0.626)\end{array}$ & $\begin{array}{l}1.306 * * \\
(0.169)\end{array}$ & $\begin{array}{l}-0.014 \\
(0.062)\end{array}$ & $\begin{array}{l}-1.391 \\
(1.482)\end{array}$ & 0.32 \\
\hline & Poultry & 0207 & $\begin{array}{c}0.282 * * \\
(0.030)\end{array}$ & & $\begin{array}{c}-0.006 \\
(0.028)\end{array}$ & $\begin{array}{l}-0.263 \\
(0.318)\end{array}$ & 0.38 \\
\hline & Swine & 0203 & $\begin{array}{l}0.669 * \\
(0.512)\end{array}$ & $\begin{array}{c}0.909 * * \\
(0.165)\end{array}$ & $\begin{array}{c}-0.004 \\
(0.048)\end{array}$ & $\begin{array}{l}-0.487 \\
(0.467)\end{array}$ & 0.29 \\
\hline \multirow{3}{*}{ Processed } & Milk & 0401 & $\begin{array}{l}0.415^{*} \\
(1.020)\end{array}$ & & $\begin{array}{c}0.273 \\
(0.248)\end{array}$ & $\begin{array}{c}1.950 \\
(5.223)\end{array}$ & 0.27 \\
\hline & Wine & 2204 & $\begin{array}{c}1.971^{* * *} * \\
(0.176)\end{array}$ & $\begin{array}{c}2.165 * * \\
(0.083)\end{array}$ & $\begin{array}{l}-0.009 \\
(0.621)\end{array}$ & $\begin{array}{l}-0.243 \\
(0.533)\end{array}$ & 0.89 \\
\hline & Sugar & 1701 & $\begin{array}{c}0.817 * * \\
(0.388)\end{array}$ & $\begin{array}{c}1.140^{* * * *} \\
(0.155)\end{array}$ & $\begin{array}{c}0.078 \\
(0.059)\end{array}$ & $\begin{array}{l}-0.030 \\
(0.161)\end{array}$ & 0.39 \\
\hline Aggregated & \multicolumn{2}{|c|}{ Agriculture } & $\begin{array}{c}0.329 * * * \\
(0.038)\end{array}$ & & $\begin{array}{c}0.027 * * \\
(0.012)\end{array}$ & $\begin{array}{l}-0.623 \\
(1.687)\end{array}$ & 0.62 \\
\hline
\end{tabular}


The measured short-run Armington elasticity for maize is 0.868 , which can be interpreted as the level at which the maize industry substitutes imported good with domestically produced goods if the price of the imported good increases by 1 per cent relative to the price of the domestic good. The long-run elasticity for maize products is 2.399 , which is very elastic, indicating the high sensitivity of maize imports to relative price changes. Looking at Table 3 above, the short-run results show that, when measuring the elasticities at the level of an individual agricultural commodity, they are more elastic relative to the elasticities of an aggregated agricultural product. For example, the short-run elasticity for aggregated agricultural products is 0.329 , while for an individual product such as sorghum it is 1.818 , for beef it is 0.911 and for grapes it is 0.717 . Both the short- and long-run Armington elasticities for grain products are highly elastic, suggesting that grain imports are the most sensitive to relative price changes. Following grain products are processed food and meat products, indicating that they are also sensitive import products. Fruit and vegetables, with the exception of grapes and tomatoes, have inelastic import demand elasticities, implying their imports are less sensitive to price changes.

The dummy variable was found to be statistically insignificant for the majority of individual products, except for wheat, grapes, and potatoes, as well as aggregate agriculture. This suggests that market deregulation and trade opening have had an effect on aggregate agriculture as well as on wheat, grapes and potato products. The abolishment of marketing control boards and the removal of tariff quotas and other trade distortionary measures led to an increase in trade for agriculture, hence the dummy variable is found to be statistically significant for aggregate agriculture. The real GDP variable, which captures the demand pressures on economic activities, is found to be statistically insignificant for all products. This can be attributed to the fact that agriculture contributes a relatively low share to total GDP in the country, measured at 2.5 per cent in 2016 (DAFF, 2018). This means that the growth in real GDP is largely driven by other sectors and less so by agricultural products, hence the statistically insignificant results found for real GDP.

The Armington elasticities presented in Table 3 above are slightly lower than, but comparable with, the results obtained in the local literature. For example, Ogundeji et al. (2010) found short-run elasticities ranging between 0.79 and 3.47 but applied quarterly data series. The reason for the lower estimates found in this paper in comparison to previous studies could be that we used annual data series, which tend to yield estimates that are closer to unit. Hillberry and Hummels (2013: 1224) reported that time-series estimates of domestic-foreign 
substitution typically find low price elasticities of import demand. Most importantly, the results shown in Table 3 above indicate that there are no outliers, which is a confidence booster for researchers who will use these elasticities to advance policy analysis and CGE modelling.

Table 4: CET export supply elasticities for individual and aggregate agriculture products

\begin{tabular}{|c|c|c|c|c|c|c|}
\hline \multirow{2}{*}{ Sub-sector } & \multirow{2}{*}{ Commodities } & \multirow{2}{*}{ HS code } & \multicolumn{2}{|c|}{ Export supply elasticity } & \multirow{2}{*}{ Dummy } & \multirow{2}{*}{ R-square } \\
\hline & & & Short-run & Long-run & & \\
\hline \multirow{3}{*}{ Grains } & Maize & 1005 & $\begin{array}{c}0.491 * * * \\
(0.183)\end{array}$ & $\begin{array}{c}0.536 * * * \\
(0.154)\end{array}$ & $\begin{array}{c}-0.094 * * * \\
(0.03)\end{array}$ & 0.57 \\
\hline & Wheat & 1001 & $\begin{array}{c}0.995 * * * \\
(0.470)\end{array}$ & $\begin{array}{c}1.707 * * * \\
(0.156)\end{array}$ & $\begin{array}{c}0.191 * * * \\
(0.105)\end{array}$ & 0.57 \\
\hline & Sorghum & 1007 & $\begin{array}{c}1.108 * * * \\
(0.406)\end{array}$ & $\begin{array}{l}1.799 * * \\
(0.172)\end{array}$ & $\begin{array}{l}-0.106 \\
(0.122)\end{array}$ & 0.61 \\
\hline \multirow{4}{*}{ Fruits } & Apples & 080810 & $\begin{array}{c}0.005 \\
(0.012) \\
\end{array}$ & & $\begin{array}{c}0.007 \\
(0.007)\end{array}$ & 0.52 \\
\hline & Grapes & 080610 & $\begin{array}{c}0.139 * * * \\
(0.036)\end{array}$ & $\begin{array}{c}0.143 \\
(0.153)\end{array}$ & $\begin{array}{l}-0.001 \\
(0.736)\end{array}$ & 0.23 \\
\hline & Oranges & 080510 & $\begin{array}{c}0.028 * * * \\
(0.099)\end{array}$ & & $\begin{array}{c}0.008 \\
(0.0006)\end{array}$ & 0.38 \\
\hline & Avocados & 080440 & $\begin{array}{c}0.412 * * * \\
(0.179)\end{array}$ & $\begin{array}{c}0.685^{* * *} * \\
(0.148)\end{array}$ & $\begin{array}{c}0.004 \\
(0.010) \\
\end{array}$ & 0.57 \\
\hline \multirow{2}{*}{ Vegetables } & Potatoes & 0701 & $\begin{array}{l}0.279 * \\
(0.158)\end{array}$ & $\begin{array}{c}0.360 * * \\
(0.170)\end{array}$ & $\begin{array}{c}0.007 \\
(0.023) \\
\end{array}$ & 0.39 \\
\hline & Tomatoes & 0702 & $\begin{array}{c}0.518 * * * \\
(0.188)\end{array}$ & $\begin{array}{c}1.064 * * * \\
(0.080)\end{array}$ & $\begin{array}{c}0.264 \\
(0.053) \\
\end{array}$ & 0.89 \\
\hline \multirow{3}{*}{ Meat } & Beef & 0201-2 & $\begin{array}{l}0.497 * \\
(0.315) \\
\end{array}$ & & $\begin{array}{c}-0.006 \\
(0.028) \\
\end{array}$ & 0.32 \\
\hline & Poultry & 0207 & $\begin{array}{c}1.219 * * * \\
(0.428)\end{array}$ & $\begin{array}{c}.657 * * * \\
(0.156)\end{array}$ & $\begin{array}{c}-0.007 \\
(0.028) \\
\end{array}$ & 0.23 \\
\hline & Swine & 0203 & $\begin{array}{c}0.796 * * \\
(0.664)\end{array}$ & $\begin{array}{c}0.973 * * \\
(0.172)\end{array}$ & $\begin{array}{c}0.031 \\
(0.040)\end{array}$ & 0.24 \\
\hline \multirow{3}{*}{ Processed } & Milk & 0401 & $\begin{array}{c}0.849 * * \\
(1.029)\end{array}$ & $\begin{array}{l}1.213 * \\
(0.170)\end{array}$ & $\begin{array}{c}0.051 * * \\
(0.09)\end{array}$ & 0.42 \\
\hline & Wine & 2204 & $\begin{array}{c}1.039 * * * \\
(0.576) \\
\end{array}$ & $\begin{array}{c}1.274 * * \\
(0.166) \\
\end{array}$ & $\begin{array}{l}-0.006 \\
(0.021) \\
\end{array}$ & 0.37 \\
\hline & Sugar & 1701 & $\begin{array}{c}0.276^{*} \\
(0.174)\end{array}$ & & $\begin{array}{c}0.083 \\
(0.057)\end{array}$ & 0.49 \\
\hline Aggregated & Agriculture & & $\begin{array}{c}0.450 * * \\
(0.169)\end{array}$ & & $\begin{array}{c}0.135 \\
(0.013) \\
\end{array}$ & 0.53 \\
\hline
\end{tabular}

Robust standard errors in parentheses: $* * * \mathrm{p}<0.01, * * \mathrm{p}<0.05, * \mathrm{p}<0.1$

\subsection{Export supply elasticity}

Using Equation 10 above, the short- and long-run results of CET export supply elasticities for South Africa's individual and aggregate agricultural commodities are presented in Table 4. The short-run estimates range from 0.005 in the case of apples to 1.219 in the case of poultry products. Similar to the Armington elasticities, grain products show relatively high elasticities, whereas fruit have the lowest estimates. For example, products such as sorghum 
and wheat have short-run elasticities of 1.108 and 0.995 respectively, suggesting that the domestic production of grain products is very responsive to annual price changes. The low export supply elasticities for fruit products suggest that the response of fruit quantities to annual relative price changes is rather sluggish.

The dummy variable for the majority of products, except for milk, maize and wheat, was found to be statistically insignificant. This suggests that the trade and market reforms adopted in South Africa post-1994 have had a limited impact in changing the production structure of many agricultural products. This could be attributed to the fact that South Africa's agricultural products has always been an export-oriented sector. However, the market and trade reforms assisted the sector to access new export markets post-1994. As was noted with the Armington elasticity for aggregate agriculture, the export supply elasticity for aggregate agriculture is lower than the majority of elasticities for individual agricultural products, implying the resistance of aggregate agricultural quantities to respond to changes in prices, keeping all other factors constant. Similarly, the long-run elasticities of all individual products, on average, are higher than the short-run elasticities. The results presented in Table 4 above provide the first econometrically estimated export supply elasticities for South Africa's agricultural products, and this will assist CGE modellers to use correct and reliable elasticities in their models.

\section{Conclusion}

In this paper, we have provided an update on Armington elasticities covering the grain, fruit, vegetable, meat and processed food products of South Africa. The short-run Armington elasticities for individual agricultural products ranged from 0.245 for oranges to 1.971 for wine, and was estimated at 0.329 for the aggregate agricultural product. These results indicate that agricultural imports are imperfect substitutes for local goods in South Africa. The shortrun export supply elasticities were found to range from 0.005 in the case of apple to 1.219 in the case of poultry products, and for aggregate agriculture it measured 0.450 . We found that the long-run elasticities for both the Armington and export supply elasticities are on average higher than the short-run elasticities, which is consistent with the literature, as in Annabi et al. (2006) and Hillberry and Hummels (2013).

The Armington and export supply elasticity results demonstrate that, at an individual product level, commodities are more sensitive to changes in international prices. This shows that there was merit in estimating the elasticities at both the aggregate and individual product level. 
From a policy perspective, the Armington results show that the import demand for grains and meat products are most sensitive to changes in prices, followed by that for processed food and fruit products. This suggest that products that exhibit a relatively high elasticity behaviour could be vulnerable to policy changes such as changes in tariff regimes. The CET elasticity suggests that most fruit producers portray sluggish transformation behaviour between products produced for the domestic and exports markets relative to changes in prices.

The availability of estimates for individual and aggregate agricultural products will enable researchers, particularly CGE modellers, to conduct policy modelling and analysis at a detailed product level. More importantly, the paper has provided a first attempt in the agricultural sector to estimate the export supply elasticities using econometric methods instead of relying on value judgments derived from the literature. As a result, this paper has provided good insight into the appropriate estimates that should be used in CGE models to analyse policy changes. The trade elasticities estimated in this paper are anticipated to assist researchers to improve the specification of CGE models by using reliable and updated elasticities. Ultimately, these estimates are expected to improve the functionality and predictive power of CGE models, thereby enhancing the quality of policy recommendations generated from these models.

\section{References}

Annabi, N., Cockburn, J., and Decaluwe, B. 2006. Functional forms and parametrization of CGE models. MPIA Working Paper, PEP-IDRC, Canada.

Armington, P.S. 1969. A theory of demand for products distinguished by place of production. International Monetary Fund Staff Papers XVI: 159-78.

De Melo, J., and Robinson, S. 1985. Product differentiation and trade dependence of the domestic price system in computable general equilibrium trade models. Development Research Discussion Paper No. DRD127, World Bank, Washington DC.

Department of Agriculture, Forestry and Fisheries (DAFF). 2018. Agricultural abstracts publication. Available from www.daff.gov.za/daffweb3/Home/Crop-Estimates/StatisticalInformation. (accessed April 4, 2018). 
Gibson, K.L. 2003. Armington elasticities for South Africa: Long and short run industry level estimates. Working paper prepared for Trade and Industrial Policy Strategies (TIPS), Hatfield, Pretoria.

Hillberry, R., and Hummels, D. 2013. Trade elasticity parameters for a computable general equilibrium model. In Handbook of computable general equilibrium modelling, ed. P.B. Dixon and D.W. Jorgenson,1213-1268. Amsterdam: North-Holland.

Kapuscinski, C.A., and Warr, P. 1999. Estimation of Armington elasticities: An application to the Philippines. Economic Modelling 16(2): 257-78.

Liebenberg, F., Pardey, P., Beddow, J., and Kirsten, J. 2015. Re-estimating South African agricultural output value, quantity and price aggregates, 1910-2010. Agrekon 54(4): 1-27.

McDonald, S., and Punt, C. 2005. General equilibrium modelling in South Africa: What the future holds. Agrekon 44(1): 60-98.

McDonald, S., and Kirsten, J.F. 1999. South African agriculture and world market changes. Agrekon 38(4): 535-47.

Naude, F., van der Merwe, F., and van Heerden, J. 1999. Estimates of Armington elasticities for the South African manufacturing sector. Journal of Studies in Economics and Econometrics 23: 41-50.

Ogundeji, A.A., Jooste, A., and Uchezuba, D. 2010. Econometric estimation of Armington elasticities for selected agricultural products in South Africa. South African Journal of Economic and Management Sciences 13(2): 123-34.

Reinert, K., and Roland-Holst, D. 1992. Armington elasticities for United States manufacturing sectors. Journal of Policy Modelling 14(5): 631-9.

Reynolds, S. 2009. Analysing the South African table grape industry within a partial equilibrium framework. Agrekon 48(2): 124-45. 
Appendix A: Table A1: Unit root test results

\begin{tabular}{|c|c|c|c|c|c|c|c|c|c|c|c|c|c|c|c|}
\hline \multirow{2}{*}{\multicolumn{2}{|c|}{ ADF test }} & \multicolumn{2}{|c|}{ Domestic quantities } & \multicolumn{2}{|c|}{ Domestic price } & \multicolumn{2}{|c|}{ Import quantities } & \multicolumn{2}{|c|}{ Import price } & \multicolumn{2}{|c|}{ Export quantities } & \multicolumn{2}{|c|}{ Export price } & \multicolumn{2}{|c|}{ GDP } \\
\hline & & \multirow{2}{*}{$\begin{array}{c}\text { Level } \\
-2,232 \\
(0,458) \\
\end{array}$} & \multirow{2}{*}{$\begin{array}{c}\text { st } \\
\text { difference } \\
-5,043 \\
(0,001)\end{array}$} & \multirow{2}{*}{$\begin{array}{c}\text { Level } \\
-5,592 \\
(0,003) \\
\end{array}$} & \multirow{2}{*}{$\begin{array}{c}\begin{array}{c}1 \text { st } \\
\text { difference }\end{array} \\
-5,720 \\
(0,000) \\
\end{array}$} & \multirow{2}{*}{$\begin{array}{c}\text { Level } \\
0,076 \\
(0,700)\end{array}$} & \multirow{2}{*}{$\begin{array}{c}\begin{array}{c}1 \mathrm{st} \\
\text { difference }\end{array} \\
-5,466 \\
(0,000)\end{array}$} & \multirow{2}{*}{$\begin{array}{c}\text { Level } \\
-3,225 \\
(0,095)\end{array}$} & \multirow{2}{*}{$\begin{array}{c}\text { 1st } \\
\text { difference }\end{array}$} & \multirow{2}{*}{$\begin{array}{c}\text { Level } \\
-0,449 \\
(0,512)\end{array}$} & \multirow{2}{*}{$\begin{array}{c}\begin{array}{c}1 \mathrm{st} \\
\text { difference }\end{array} \\
-6,584 \\
(0,000)\end{array}$} & \multirow{2}{*}{$\begin{array}{c}\text { Level } \\
-1,862 \\
(0,345)\end{array}$} & \multirow{2}{*}{$\begin{array}{c}\text { st } \\
\text { difference }\end{array}$} & \multirow{2}{*}{$\begin{array}{c}\text { Level } \\
1,515 \\
(1,000)\end{array}$} & \multirow{2}{*}{$\begin{array}{c}\begin{array}{c}1 \mathrm{st} \\
\text { difference }\end{array} \\
-3,704 \\
(0,035)\end{array}$} \\
\hline & Maize & & & & & & & & & & & & & & \\
\hline \multirow[t]{2}{*}{ Grains } & Sorghum & $\begin{array}{l}-1,368 \\
(0,586)\end{array}$ & $\begin{array}{l}-7,189 \\
(0,000)\end{array}$ & $\begin{array}{l}-3,338 \\
(0,078)\end{array}$ & $\begin{array}{l}-6,145 \\
(0,000)\end{array}$ & $\begin{array}{c}0,145 \\
(0,721)\end{array}$ & $\begin{array}{l}-7,527 \\
(0,000)\end{array}$ & $\begin{array}{l}-0,999 \\
(0,278)\end{array}$ & $\begin{array}{l}-7,862 \\
(0,000) \\
\end{array}$ & $\begin{array}{l}-1,111 \\
(0,236)\end{array}$ & $\begin{array}{l}-7,483 \\
(0,000)\end{array}$ & $\begin{array}{l}-2,741 \\
(0,077)\end{array}$ & $\begin{array}{l}-6,269 \\
(0,000)\end{array}$ & $\begin{array}{c}1,515 \\
(1,000)\end{array}$ & $\begin{array}{l}-3,704 \\
(0,035)\end{array}$ \\
\hline & Wheat & $\begin{array}{l}-3,667 \\
(0,037)\end{array}$ & $\begin{array}{c}-8,830 \\
(0,000)\end{array}$ & $\begin{array}{c}-0,800 \\
(0,806)\end{array}$ & $\begin{array}{l}-5,457 \\
(0,000)\end{array}$ & $\begin{array}{c}-4,413 \\
(0,001)\end{array}$ & $\begin{array}{r}-10,332 \\
(0,000)\end{array}$ & $\begin{array}{l}-3,310 \\
(0,027)\end{array}$ & $\begin{array}{l}-6,662 \\
(0,000)\end{array}$ & $\begin{array}{c}-0,734 \\
(0,391)\end{array}$ & $\begin{array}{l}-6,735 \\
(0,000)\end{array}$ & $\begin{array}{l}-3,036 \\
(0,041)\end{array}$ & $\begin{array}{l}-7,768 \\
(0,000)\end{array}$ & $\begin{array}{c}1,515 \\
(1,000)\end{array}$ & $\begin{array}{l}-3,704 \\
(0,035)\end{array}$ \\
\hline \multirow{4}{*}{ Fruits } & Apple & $\begin{array}{l}-1,271 \\
(0,183)\end{array}$ & $\begin{array}{l}-10,121 \\
(0,000)\end{array}$ & $\begin{array}{l}-2,249 \\
(0,449)\end{array}$ & $\begin{array}{l}-7,280 \\
(0,000)\end{array}$ & $\begin{array}{c}-1,271 \\
(0,1835) \\
\end{array}$ & $\begin{array}{l}-10,121 \\
(0,000) \\
\end{array}$ & $\begin{array}{l}-0,8685 \\
(0,785)\end{array}$ & $\begin{array}{l}-9,584 \\
(0,000)\end{array}$ & $\begin{array}{c}-1,789 \\
(0,3794) \\
\end{array}$ & $\begin{array}{l}-10,247 \\
(0,000)\end{array}$ & $\begin{array}{l}-1,950 \\
(0,306)\end{array}$ & $\begin{array}{l}-6,625 \\
(0,000)\end{array}$ & $\begin{array}{c}1,515 \\
(1,000)\end{array}$ & $\begin{array}{l}-3,704 \\
(0,035)\end{array}$ \\
\hline & Grapes & $\begin{array}{c}0,534 \\
(0,826)\end{array}$ & $\begin{array}{l}-6,417 \\
(0,000)\end{array}$ & $\begin{array}{l}-1,086 \\
(0,710)\end{array}$ & $\begin{array}{l}-11,430 \\
(0,000)\end{array}$ & $\begin{array}{c}0,274 \\
(0,760)\end{array}$ & $\begin{array}{l}-7,426 \\
(0,000)\end{array}$ & $\begin{array}{l}-0,888 \\
(0,322)\end{array}$ & $\begin{array}{l}-11,467 \\
(0,000)\end{array}$ & $\begin{array}{l}-1,228 \\
(0,651)\end{array}$ & $\begin{array}{l}-8,444 \\
(0,000)\end{array}$ & $\begin{array}{l}-1,671 \\
(0,436)\end{array}$ & $\begin{array}{l}-12,018 \\
(0,000)\end{array}$ & $\begin{array}{c}1,515 \\
(1,000)\end{array}$ & $\begin{array}{l}-3,704 \\
(0,035)\end{array}$ \\
\hline & Oranges & $\begin{array}{l}-1,620 \\
(0,764)\end{array}$ & $\begin{array}{c}-6,132 \\
(0,000) \\
\end{array}$ & $\begin{array}{l}-1,592 \\
(0,775) \\
\end{array}$ & $\begin{array}{c}-5,618 \\
(0,000) \\
\end{array}$ & $\begin{array}{c}0,126 \\
(0,716) \\
\end{array}$ & $\begin{array}{c}-9,394 \\
(0,000)\end{array}$ & $\begin{array}{c}0,804 \\
(0,881) \\
\end{array}$ & $\begin{array}{l}-7,545 \\
(0,000) \\
\end{array}$ & $\begin{array}{c}-3,089 \\
(0,124) \\
\end{array}$ & $\begin{array}{l}-7,400 \\
(0,000) \\
\end{array}$ & $\begin{array}{c}-3,662 \\
(0,383) \\
\end{array}$ & $\begin{array}{c}-6,357 \\
(0,000) \\
\end{array}$ & $\begin{array}{c}1,515 \\
(1,000) \\
\end{array}$ & $\begin{array}{c}-3,704 \\
(0,035)\end{array}$ \\
\hline & Avocados & $\begin{array}{l}-2,309 \\
(0,418)\end{array}$ & $\begin{array}{l}-12,129 \\
(0,000)\end{array}$ & $\begin{array}{l}-3,033 \\
(0,037)\end{array}$ & $\begin{array}{l}-6,476 \\
(0,000)\end{array}$ & $\begin{array}{l}-0,562 \\
(0,974)\end{array}$ & $\begin{array}{l}-4,642 \\
(0,004)\end{array}$ & $\begin{array}{c}0,029 \\
(0,685)\end{array}$ & $\begin{array}{l}-5,800 \\
(0,000)\end{array}$ & $\begin{array}{c}1,521 \\
(0,965)\end{array}$ & $\begin{array}{l}-5,001 \\
(0,000)\end{array}$ & $\begin{array}{l}-2,231 \\
(0,458)\end{array}$ & $\begin{array}{l}-6,233 \\
(0,000)\end{array}$ & $\begin{array}{c}1,515 \\
(1,000)\end{array}$ & $\begin{array}{l}-3,704 \\
(0,035)\end{array}$ \\
\hline \multirow{2}{*}{ Vegetables } & Potatoes & $\begin{array}{c}-0,703 \\
(0,831)\end{array}$ & $\begin{array}{l}-7,405 \\
(0,000)\end{array}$ & $\begin{array}{c}-0,082 \\
(0,959)\end{array}$ & $\begin{array}{l}-8,759 \\
(0,000)\end{array}$ & $\begin{array}{l}-0,424 \\
(0,522)\end{array}$ & $\begin{array}{c}-9,813 \\
(0,000)\end{array}$ & $\begin{array}{l}-0,263 \\
(0,583)\end{array}$ & $\begin{array}{l}-9,691 \\
(0,000)\end{array}$ & $\begin{array}{l}-3,181 \\
(0,104)\end{array}$ & $\begin{array}{l}-6,420 \\
(0,000)\end{array}$ & $\begin{array}{c}0,237 \\
(0,749)\end{array}$ & $\begin{array}{c}-7,982 \\
(0,0000) \\
\end{array}$ & $\begin{array}{c}1,515 \\
(1,000)\end{array}$ & $\begin{array}{l}-3,704 \\
(0,035)\end{array}$ \\
\hline & Tomatoes & $\begin{array}{l}-1,390 \\
(0,575)\end{array}$ & $\begin{array}{c}-8,603 \\
(0,000)\end{array}$ & $\begin{array}{c}0,434 \\
(0,981)\end{array}$ & $\begin{array}{l}-6,230 \\
(0,000)\end{array}$ & $\begin{array}{l}-2,590 \\
(0,140)\end{array}$ & $\begin{array}{l}-6,363 \\
(0,000)\end{array}$ & $\begin{array}{c}-0,692 \\
(0,409)\end{array}$ & $\begin{array}{l}-8,753 \\
(0,000)\end{array}$ & $\begin{array}{l}-0,720 \\
(0,828)\end{array}$ & $\begin{array}{c}-9,142 \\
(0,000)\end{array}$ & $\begin{array}{c}-0,376 \\
(0,541)\end{array}$ & $\begin{array}{l}-9,599 \\
(0,000)\end{array}$ & $\begin{array}{c}1,515 \\
(1,000)\end{array}$ & $\begin{array}{c}-3,704 \\
(0,035)\end{array}$ \\
\hline \multirow{3}{*}{ Meat } & Beef & $\begin{array}{l}-0,467 \\
(0,886)\end{array}$ & $\begin{array}{c}-6,102 \\
(0,000)\end{array}$ & $\begin{array}{l}-2,667 \\
(0,255)\end{array}$ & $\begin{array}{c}-5,082 \\
(0,001)\end{array}$ & $\begin{array}{c}-0,020 \\
(0,669)\end{array}$ & $\begin{array}{c}-5,112 \\
(0,000)\end{array}$ & $\begin{array}{l}-1,038 \\
(0,925)\end{array}$ & $\begin{array}{l}-4,788 \\
(0,002)\end{array}$ & $\begin{array}{l}-0,630 \\
(0,851)\end{array}$ & $\begin{array}{c}-6,453 \\
(0,000)\end{array}$ & $\begin{array}{c}0,335 \\
(0,776)\end{array}$ & $\begin{array}{l}-9,205 \\
(0,000)\end{array}$ & $\begin{array}{c}1,515 \\
(1,000)\end{array}$ & $\begin{array}{c}-3,704 \\
(0,035)\end{array}$ \\
\hline & Poultry & $\begin{array}{c}-0,535 \\
(0,871) \\
\end{array}$ & $\begin{array}{c}-3,943 \\
(0,004) \\
\end{array}$ & $\begin{array}{c}-2,082 \\
(0,252) \\
\end{array}$ & $\begin{array}{c}-5,979 \\
(0,000) \\
\end{array}$ & $\begin{array}{c}-3,858 \\
(0,026) \\
\end{array}$ & $\begin{array}{c}-5,846 \\
(0,000) \\
\end{array}$ & $\begin{array}{c}-3,058 \\
(0,401) \\
\end{array}$ & $\begin{array}{c}-7,821 \\
(0,000)\end{array}$ & $\begin{array}{l}-1,057 \\
(0,721) \\
\end{array}$ & $\begin{array}{c}-5,034 \\
(0,000)\end{array}$ & $\begin{array}{l}-3,537 \\
(0,012) \\
\end{array}$ & $\begin{array}{c}-7,820 \\
(0,000)\end{array}$ & $\begin{array}{c}1,515 \\
(1,000)\end{array}$ & $\begin{array}{c}-3,704 \\
(0,035) \\
\end{array}$ \\
\hline & Swine & $\begin{array}{c}-0,379 \\
(0,902)\end{array}$ & $\begin{array}{c}-5,570 \\
(0,000)\end{array}$ & $\begin{array}{c}-2,689 \\
(0,872)\end{array}$ & $\begin{array}{c}-8,530 \\
(0,000)\end{array}$ & $\begin{array}{l}-1,840 \\
(0,664)\end{array}$ & $\begin{array}{c}-4,787 \\
(0,002)\end{array}$ & $\begin{array}{c}-3,114 \\
(0,034)\end{array}$ & $\begin{array}{c}-9,795 \\
(0,000)\end{array}$ & $\begin{array}{l}-1,959 \\
(0,302)\end{array}$ & $\begin{array}{l}-7,068 \\
(0,000)\end{array}$ & $\begin{array}{c}-3,534 \\
(0,056)\end{array}$ & $\begin{array}{c}-7,101 \\
(0,000)\end{array}$ & $\begin{array}{c}1,515 \\
(1,000)\end{array}$ & $\begin{array}{c}-3,704 \\
(0,035)\end{array}$ \\
\hline \multirow{3}{*}{ Processed food } & Milk & $\begin{array}{l}-2,530 \\
(0,312)\end{array}$ & $\begin{array}{c}-7,591 \\
(0,000)\end{array}$ & $\begin{array}{c}-1,444 \\
(0,548)\end{array}$ & $\begin{array}{l}-6,261 \\
(0,000)\end{array}$ & $\begin{array}{c}-1,424 \\
(0,559)\end{array}$ & $\begin{array}{c}-6,770 \\
(0,000)\end{array}$ & $\begin{array}{c}0,111 \\
(0,711)\end{array}$ & $\begin{array}{c}-10,868 \\
(0,000)\end{array}$ & $\begin{array}{c}-0,423 \\
(0,894)\end{array}$ & $\begin{array}{l}-7,839 \\
(0,000)\end{array}$ & $\begin{array}{c}-0,178 \\
(0,614)\end{array}$ & $\begin{array}{l}-9,283 \\
(0,000)\end{array}$ & $\begin{array}{c}1,515 \\
(1,000)\end{array}$ & $\begin{array}{l}-3,704 \\
(0,035)\end{array}$ \\
\hline & Sugar & $\begin{array}{c}-2,139 \\
(0,231)\end{array}$ & $\begin{array}{c}-8,311 \\
(0,000)\end{array}$ & $\begin{array}{c}-3,874 \\
(0,024)\end{array}$ & $\begin{array}{c}-5,5155 \\
(0,001)\end{array}$ & $\begin{array}{c}-2,0332 \\
(0,272)\end{array}$ & $\begin{array}{c}-8,235 \\
(0,000)\end{array}$ & $\begin{array}{c}-3,980 \\
(0,040)\end{array}$ & $\begin{array}{l}-11,01 \\
(0,000)\end{array}$ & $\begin{array}{c}-2,144 \\
(0,229)\end{array}$ & $\begin{array}{l}-5,476 \\
(0,000)\end{array}$ & $\begin{array}{l}-1,781 \\
(0,383)\end{array}$ & $\begin{array}{c}-5,011 \\
(0,000)\end{array}$ & $\begin{array}{c}1,515 \\
(1,000)\end{array}$ & $\begin{array}{l}-3,704 \\
(0,035)\end{array}$ \\
\hline & Wine & $\begin{array}{l}-1,490 \\
(0,526)\end{array}$ & $\begin{array}{l}-5,646 \\
(0,000)\end{array}$ & $\begin{array}{c}-0,765 \\
(0,816)\end{array}$ & $\begin{array}{l}-5,166 \\
(0,000)\end{array}$ & $\begin{array}{c}-0,455 \\
(0,690)\end{array}$ & $\begin{array}{l}-66,061 \\
(0,000)\end{array}$ & $\begin{array}{l}-1,881 \\
(0,336)\end{array}$ & $\begin{array}{l}-6,761 \\
(0,000)\end{array}$ & $\begin{array}{c}-0,524 \\
(0,874)\end{array}$ & $\begin{array}{l}-6,039 \\
(0,000)\end{array}$ & $\begin{array}{l}-1,767 \\
(0,390)\end{array}$ & $\begin{array}{l}-6,486 \\
(0,000)\end{array}$ & $\begin{array}{c}1,515 \\
(1,000)\end{array}$ & $\begin{array}{l}-3,704 \\
(0,035)\end{array}$ \\
\hline Aggregate & Agriculture & $\begin{array}{c}-2,217 \\
(0,203)\end{array}$ & $\begin{array}{c}-8,397 \\
(0,000)\end{array}$ & $\begin{array}{c}-1,688 \\
(0,427)\end{array}$ & $\begin{array}{c}-6,063 \\
(0,000)\end{array}$ & $\begin{array}{c}-3,659 \\
(0,092)\end{array}$ & $\begin{array}{c}-7,629 \\
(0,000)\end{array}$ & $\begin{array}{c}-0,0822 \\
(0,673)\end{array}$ & $\begin{array}{c}-5,536 \\
(0,000)\end{array}$ & $\begin{array}{c}-0,229 \\
(0,596)\end{array}$ & $\begin{array}{c}-8,003 \\
(0,000)\end{array}$ & $\begin{array}{c}-1,480 \\
(0,532)\end{array}$ & $\begin{array}{c}-8,065 \\
(0,000)\end{array}$ & $\begin{array}{c}1,515 \\
(1,000)\end{array}$ & $\begin{array}{c}-3,704 \\
(0,035)\end{array}$ \\
\hline
\end{tabular}

Note: $p$-values in parentheses 